\title{
DEVELOPMENT OF COUNSELING WITH SIMULATION METHOD FOR THE NEW BORN CARE SERVICE AMONG PREGNANT WOMEN AT BENDOSARI COMMUNITY HEALTH CENTER, SUKOHARJO, CENTRAL JAVA
}

\author{
Surati Ningsih, Sri Setiyo Ningrum
}

School of Sciences Bhakti Mulia, Sukoharjo, Central Java

\begin{abstract}
Background: Postpartum psychological disorders is a mood disorder that can affect women after childbirth. Mothers with postpartum depression experience feelings of extreme sadness, anxiety, and exhaustion that may make it difficult for them to complete daily care activities for themselves or for others. The health workers can play an important role of screening and treating psychological postpartum. Treatment options include psychotherapy. This study aimed to investigate the development of counseling with simulation method for the new born care service among pregnant women at Bendosari Community Health Center, Sukoharjo, Central Java.

Subjects and Method: This was a randomized controlled trial with posttest-only control group design conducted at Bendosari Community Health Center, Sukoharjo Regency. A sample of postpartum mothers with gestational age $\geq 37$ weeks was selected for this study. It was divided into two groups: intervention group and control group. The dependent variable was postpartum psychological disorder. The independent variable was newborn care counseling with simulation. The data on postpartum psychological disorder was measured by Edinburgh Postnatal Depression Scale and tested by independent t-test.
\end{abstract}

Results: Postpartum psychological disorders was lower in intervention group than control group and it was statistically significant.

Conclusion: Newborn care counseling with simulation is effective to reduce postpartum psychological disorder.

Keywords: newborn care, counseling, simulation, postpartum psychological disorders

Correspondence:

Surati Ningsih, School of Sciences Bhakti Mulia, Sukoharjo, Central Java. Email: Mobile: $0271592577,081393367210$. 